\title{
AHORA BUSQUEMOS JUNTOS CREYENDO, PARA QUE DESPUÉS DISFRUTEMOS VIENDO (S. 261, 3)
}

\author{
Pablo Antonio Morillo Rey \\ Centro de Estudios Teológicos-Sevilla
}

\section{RESUMEN / ABSTRACT}

Enmarcados en el quinto centenario del nacimiento de Santa Teresa de Jesús, presentamos el siguiente trabajo, en donde se intenta poner de manifiesto las posibles influencias existentes entre San Agustín de Hipona y la primera Doctora de la Iglesia Universal. Para ello, se invita al lector a realizar un breve recorrido por la vida teresiana, desde su infancia hasta su muerte acaecida en Alba de Tormes la noche del 15 de Octubre del 1582. Así, ambos Doctores -con la eminencia de sus doctrinas y la santidad de sus vidas-comunican al mundo que "quien a Dios tiene nada le falta", pues "sólo Él es el bien que hace feliz a la criatura" (civ. Dei XII, 1,2).

Being immersed in the Fifth Centennial of St. Theresa's Birth, we present the following paper, in which we pretend to explain the nexus between St. Agustin from Hipona and the first woman being Doctor of Catholic Church. For doing this, we invite readers to shortly remember her life, beginning with her childhood until her death at Alba de Tormes, the night of October 15th, 1582. Therefore, both Doctors - by means of their wisdom and life sanctity- say to the world that "the one who possesses God nothing missed" because "Only God is making happy any creature". 
"Comencé a encomendarme mucho a este glorioso santo" (V. 9,8)

\section{INTRODUCCIÓN}

Su Santidad el Papa Francisco (1936) ha tenido a bien declarar para nuestro país, con motivo de la celebración del $\mathrm{V}$ centenario del nacimiento ${ }^{1}$ de la "eximia carmelita" 2 Teresa de Jesús ${ }^{3}$ (1515-1582), año jubilar teresiano el próximo 2015.

Tan grata y gratificante noticia, fue dada a conocer en el transcurso de una Eucaristía celebrada en la catedral abulense ${ }^{4}$ como conmemoración del 400 aniversario de su beatificación ${ }^{5}$. Así, será el próximo 15 de Octubre del presente año 2014 cuando se inicie dicha efeméride, abarcando hasta el 15 de Octubre de 2015.

De esta manera, se pretende que en todas las diócesis españolas se obtenga un mayor conocimiento del mensaje teresiano, un mensaje repleto de santidad y amor a Dios, pues -como bien apuntó el Santo Papa Juan Pablo II (1920-2005)- ella es "el faro luminoso de la Iglesia en España”. ${ }^{6}$

Por todo ello, la Iglesia española desea obtener grandes frutos espirituales de este año, a la vez que se une a la Santa para exclamar: "bien sabe mi Señor que no pretendo otra cosa en esto, que sea alabado y engrandecido" .

"España -como bien señaló Pablo VI (1897-1978)- la considera una de sus grandes glorias" más allá, haciendo posible que todos (creyentes o ateos, católicos

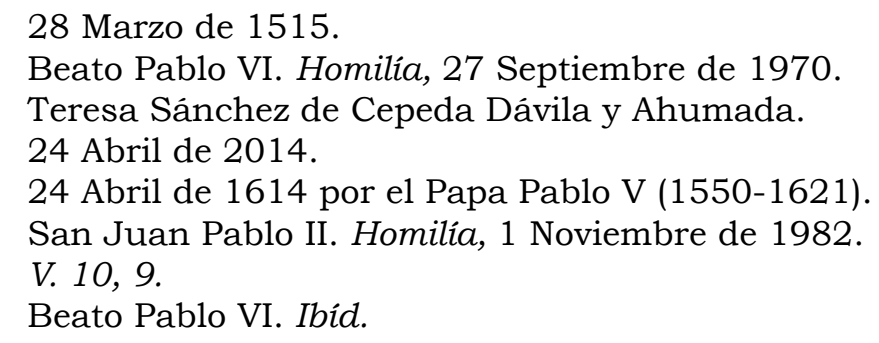


o de otras confesiones) se sientan atraídos por la eminencia de su doctrina. Todo ello, junto a su vida santa, conducirá al Papa Gregorio XV (1554-1623) a canonizarla el 12 de Marzo del año 1622, así como a su posterior proclamación como Doctora de la Iglesia por el beato Pablo VI el 27 de Septiembre del año 1970.

Por otro lado, el Papa emérito Benedicto XVI (1927) la calificó de "verdadera maestra de vida cristiana para los fieles de todos los tiempos", pues ella provoca en el hombre ese "deseo o anhelo de Dios" del que se encuentra tan carente y necesitado, en medio de una sociedad con "escasos valores morales y espirituales".

Al mismo tiempo, esta "andariega de Dios"10 nos enseña a entablar un diálogo con El, a ser sus "amigos", en una palabra, a desear verle, pues "Quiero ver a Dios"11.

Pero, "Santa Teresa, esa mujer excepcional...y, sin embargo, envuelta toda ella de humildad, de penitencia y sencillez"12, se apoya y alimenta con la lectura de los Padres de la Iglesia. No obstante, entre todos ellos halla uno con el que, especialmente, encuentra cierta sintonia: Agustín de Hipona (354-430).

Así, y a la temprana edad de 16 años, la joven Teresa -al quedar huérfana de madre ${ }^{13}$ - es internada ${ }^{14}$ en el prestigioso monasterio que las religiosas agustinas regentaban en Ávila: Nuestra Señora de Gracia. Es aquí, donde permanece durante año y medio (Julio 1531- Diciembre 1532) como "doncella seglar", el lugar en el que entra en contacto con "el Padre más grande de la Iglesia latina"15, "el gran enamorado de Dios"16.

\footnotetext{
Benedicto XVI. Audiencia General, 2 Febrero de 2011.

San Juan Pablo II. Homilia, 1 Noviembre de 1982.

V. $1,5$.

Beato Pablo VI. Homilia, 27 Septiembre de 1970.

3 Beatriz Dávila y Ahumada (1495-1528).

14 Por su padre Alonso Sánchez de Cepeda (1471-1544), pues "porque haberse mi hermana casado y quedar sola sin madre, no era bien" (V. 2, 6).

15 Benedicto XVI. Audiencia General, 9 Enero de 2008.

16 Benedicto XVI. Audiencia General, 27 Febrero de 2008.
} 
Dicho convento $-\mathrm{y}$ según indicaciones del carmelita Silverio de Santa Teresa (1878-1954)- "tenía fama de muy observante y recogido y de guardar con mucho rigor la clausura"17, algo que -aunque admiraba ${ }^{18}$ - no era para ella, pues esta vida austera y mortificada era de "extremos demasiados"19.

No obstante, y gracias a la esmerada educación piadosa que allí recibió -junto con las lecturas de los clásicos de la espiritualidad franciscana- su vida se desenvuelve en el recogimiento y la oración, al mismo tiempo que comienza a sentir la pobreza de sus sentimientos religiosos, una pobreza que le conduciría -incluso- a envidiar las lágrimas que algunas monjas derramaran en oración, puesto que "habiala mucha envidia, porque era tan recio mi corazón en este caso que, si leyera toda la pasión, no llorara una lágrima. Esto me causaba pena". ${ }^{20}$

Lo cierto y evidente es que, "santa tan singular y tan grande"21, recuperó en este monasterio agustiniano su vida de piedad, pues andaba con "niñerías nonada buenas". 22

Pero, no sería hasta el año 1554, a los 39 años de edad, cuando providencialmente caiga en sus manos el libro que más conmovió e impactó en su vida y por el que decide entregarse enteramente a Dios: Las Confesiones (397-398), del "gran hombre y santo"23 Agustín de Hipona, por el cual "estuve por gran rato que toda me deshacía en lágrimas y entre mí misma con gran aflicción y fatiga..." 24

Dicha obra serviria de modelo para elaborar posteriormente el de su Vida, ya que es evidente en esta obra teresiana -al igual que en

17 Silverio de Santa Teresa. Historia del Carmen Descalzo en España, Portugal y América. Vol. I (Santa Teresa en el siglo y monja de la Encarnación (1515-1561)). Tipografia "El Monte Carmelo", Burgos, 1935, pp. 101 y 105, nota 2.

18 "Holgábame de ver tan buenas monjas, que lo eran mucho las de aquella casa, y de gran honestidad y religión y recatamiento" $(V .2,8)$.

19 V. 3, 2.

20 V. 3, 1.

21 Beato Pablo VI. Homilía, 27 Septiembre de 1970.

22 V. $2,3$.

${ }^{23}$ Francisco. Homilía, 28 Agosto de 2013.

${ }^{24}$ V. $9,8$. 
el Castillo interior (como lo intitula la misma Santa) o Las Moradasun "cierto aire familiar", como podremos ver a continuación:

\section{2. "CONFESIONES" AGUSTINIANAS: ESPEJO DE LA “VIDA" TERESIANA}

"Como comencé a leer las "Confesiones" pareciame ver yo alli"25.

Con estas palabras, la "sabia Teresa"26 nos indica en el libro de la Vida (1552-1565) que leyó detenidamente la obra agustiniana "que es más frecuente y con más deleite leida"27.

Como ya señalamos anteriormente, el libro llega a sus manos casualmente, "pues yo no las procuré, ni nunca las habia visto"28. Sin embargo, su lectura caló hondo en su alma, sirviéndole de "espejo donde reflejar su situación personal".

Además, gracias a dicha obra, Teresa se adentra en la literatura, puesto que en ésta encuentra el modelo y el molde para la obra que necesitaba escribir: "el precedente más directo y el modelo más claro tanto del libro de la "Vida" como del componente biográfico que subyace en toda la obra de nuestra escritora"29.

No obstante, hemos de advertir que leyó esta obra en su primera versión castellana del agustino portugués Fray Sebastián Toscano (1515-1583), publicada el día 15 de Enero del año 1554. Ésta, tan sólo contenía los diez primeros libros -en vez de los trece que la integran- (de ahí concluimos que la Santa sólo leyese los referentes a la vida agustiniana). Asi, del libro XI solamente se tradujo el capitulo primero y segundo, no habiendo rastro alguno de los libros XII y XIII, ya que el traductor no los consideró como "confesiones",

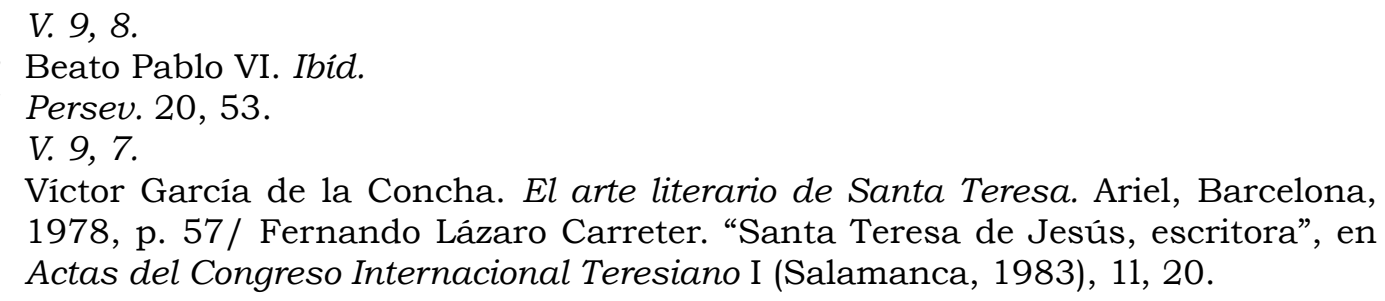


sino como "exposiciones", pues "Mi intento en este trabajo fue solamente dar noticia de la vida de San Agustín según él la escribe y lo que queda no hace a este propósito ni es de calidad que, puesto en romance, se dejaría entender de todos"30, pues como bien señaló el propio autor "los libros que van del primero al décimo tratan de mí, los tres restantes hablan de la Sagrada Escritura"31.

Pero, conviene tener muy en cuenta que antes de iniciar la lectura de dicha obra, acaece en su vida un insólito acontecimiento que la marcará muy profundamente: el descubrimiento "fortuito" de la imagen de un "Cristo muy llagado" 32 . Gracias a éste, se despierta en ella "ciertos sentimientos de piedad y de ingratitud" que la llevarán a ver representada en dicha imagen todo el amor inimaginable e increíble que Dios tiene por cada uno de los hombres, incluida ella misma. Así, sólo dicho amor le encaminó a sufrir la tortura más cruel, algo que le hará reflexionar sobre su "profunda ingratitud", así como su "desagradecida actitud". De esta forma, inmersas en sus "ruines costumbres" (Siendo tan ruin...mi ruin vida"33) será incapaz de agradecer "aquellas llagas" 34 , algo que (al igual que María Magdalena) le conducirá a arrojarse a los pies del Señor "con grandísimo derramamiento de lágrimas" e "implorando perdón y ayuda para no volver a ofenderle ya de una vez"35.

Por tanto, este encuentro vivencial con la mencionada imagen caló hondamente en su vida, al mismo tiempo que ayudó a depositar toda su confianza en $\mathrm{El}$, pues irá "mejorando mucho desde entonces"36. Dicha experiencia, redactada ocho u once años más tarde (pues ni ella misma estará segura sobre la fecha o el mes exacto en que ocurrió) nunca se borró de su mente ni de su corazón, acontecimiento que -sin duda- le sirvió de "propedéutica" para la lectura de las Confesiones.

\footnotetext{
30 San Agustín. Confesiones (Ed. Fray Sebastián Toscano). Fundación Universitaria Española y Universidad Pontificia de Salamanca, Madrid, 1996, p. 307.

Retr. II, 6, 1.

V. $9,1$.

33 V. $19,4$.

$34.9,1$.

35 V. 9, 1.

36 V. 9, 3.
} 
Santa Teresa se identifica de tal forma con el protagonista de esta obra que, incluso, cree la voz del huerto de Milán ${ }^{37}$ como dirigida a ella misma:

"Cuando llegué a su conversión y leí como oyó aquella voz en el huerto, no me parecía sino que el Señor me la dio a mí, según sintió mi corazón”38.

Así, tanto la contemplación ante la imagen del Cristo "muy llagado" como la lectura detenida de las Confesiones, no corroboraron sino la decisión que esta "virgen de Castilla"39 había tomado: "darme del todo a Dios" $"$.

De esta forma, el Obispo de Hipona le estimulaba y ayudaba con su ejemplo, puesto que él "también era (por haber sido) pecador", pues "en los santos que después de serlo el Señor tomó a sí hallaba yo mucho consuelo, pareciéndome en ellos habia da hallar ayuda $y$ que como los habia el Señor perdonado podía hacer a mi" ${ }^{\prime \prime}$.

Sin embargo, Teresa creerá ser aún más pecadora que el propio Agustín (“...según mis culpas, aún me parece merecía más castigo" puesto que él -una vez convertido- no volvió a caer, a "ofender a Dios nuevamente", aunque la misericordia divina todo lo puede. Así lo expresa ella misma: "salvo que en una cosa me desconsolaba, como he dicho, que a ellos solo una vez los habia el Señor llamado y no tornaban a caer, y a mi ya eran tantas, que eso me fatigaba. Mas considerando el amor que me tenía, tornaba a animarme, que de su misericordia jamás desconfié; de mi, muchas veces" ${ }^{\prime 3}$.

No obstante, y a pesar de las numerosas coincidencias o similitudes entre ambas vidas, no podemos hallar en ella esa "búsqueda intelectual y minuciosa propia del filósofo o teólogo",

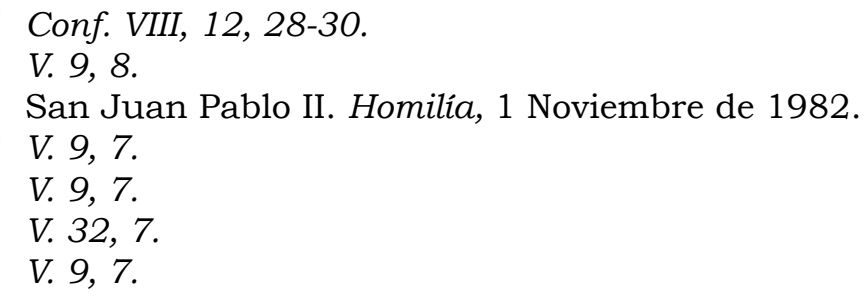


es decir, la Santa reformadora no recurrió al "intellego ut credas" agustiniano, pues "El Padre común de la Europa cristiana"44 cree será necesario usar la razón para llegar a la fe, siendo ésta la que después dirija a aquélla (tengamos en cuenta que para él siempre será la fe el punto de partida, pues "Intellectus merces est fidei"

Sin embargo, esta "hija singularmente amada de la Sabiduria divina" 46 se instala, desde un primer momento, en esta segunda parte, puesto que es el amor el que realmente deberá prevalecer: "Lo importante no es pensar mucho, sino amar mucho" 4 .

Por otra parte, tampoco hemos de olvidar que ya San Agustín señaló dicho amor como "algo imprescindible" para poder mover al hombre, pues, "Pondus meum amor meus: eo feror, quocumque feror"48, al mismo tiempo que nos hablará acerca de la existencia de "dos amores" (el amor a Dios y el amor a sí mismo) que se encuentran en "constante lucha", lucha que -seguramenteimpactó a la propia Santa, ya que también ella libraba "esta batalla en su corazón":

"Pasaba una vida trabajosísima...Por una parte, me llamaba Dios; por otra, yo seguía al mundo. Dábanme gran contento todas las cosas de Dios; tenianme atadas las del mundo. Parece que quería concertar estos dos contrarios, tan enemigos uno del otro, como es vida espiritual y contentos y gustos y pasatiempos sensuales" $"$.

Pero, para poner de relieve ese "amor misericordioso de Dios" en su vida, esta "prodigiosa y mística escritora" decide elaborar una de sus principales obras: el libro de la Vida, que ella misma intituló como Libro de las misericordias de Dios ${ }^{51}$, es decir, de las maravillas que El realizó en su vida. Así, su objetivo sería poner de manifiesto que "su Majestad...nunca se cansa de dar ni se pueden agotar sus

\footnotetext{
San Juan Pablo II. Augustinum Hipponensem, 28 Agosto de 1986, II.

S. $126,1$.

46 San Juan Pablo II. Homilia, 1 Noviembre de 1982.

47 M. IV, $1,7$.

48 Conf. XIII, 9, 10.

49 V. 7, 17.

50 Beato Pablo VI. Homilia, 27 Septiembre de 1970.

51 Cta. 415, 1.
} 
misericordias: no nos cansemos nosotros de recibir. Sea bendito para siempre, amén, y alábenle todas las cosas"52.

He aquí nuevamente otra coincidencia con el "más grande de los Padres y uno de los genios más eminentes de la humanidad"53, pues también él nos advirtió que "los trece libro de mis Confesiones alaban a Dios justo, por mis males $y$ mis bienes, $y$ despiertan hacia el humano entendimiento y corazón" $"$.

En definitiva, ambas obras arrancan y provocan un cierto impacto tanto en las vidas como en las almas de todos aquellos que se acercan a leerlas, caso de la "gran mujer" Edith Stein (18911942), Santa Teresa Benedicta de la Cruz, la cual se convirtió al catolicismo tras pasar una noche entera leyendo este libro de la Vida: "Cuando cerré el libro me dije: esta es la verdad"

De esta forma, y como bien señala González de Cardedal (1934), "está alejada de la biografia moderna y sobre todo del impudor de aquellos relatos que se convierten en pedestal para mostrar vidas desnudas sin belleza ni dignidad de fondo"56,

Por todo ello -y haciéndonos eco de las palabras de Fray Luis de León (1527/8-1591)- podemos concluir afirmando que "Yo no conoci ni vi a la Madre Teresa de Jesús mientras estuvo en la tierra; mas agora que vive en el cielo la conozco y veo casi siempre en dos imágenes vivas que nos dejó de si, que son sus hijas y sus libros; que, a mi juicio, son también testigos fieles y mayores de toda concepción de su grande virtud"57.

\footnotetext{
V. 19, 15.

3 Johannes Quasten. Patrología. La edad de oro de la literatura latina. BAC, Madrid, 1993, Vol. II, c. IV, pp. 405-553.

4 Retr. II, 6.

5 San Juan Pablo II. Homilía, 1 Mayo de 1987.

Olegario González de Cardedal. "Teresa de Jesús”, 11 Octubre de 2001.

57 Carta-Prólogo de Fray Luis de León a la edición príncipe. Madrid, 15 Septiembre de 1587, en Santa Teresa de Jesús. Libro de la Vida. Algaba Ediciones, Madrid, 2007, p. 39.
} 


\section{TERESA DE JESÚS: "ERES PALABRA UNIVERSAL DE EXPE- RIENCIA DE DIOS" ${ }^{58}$}

Teresa de Jesús, la Santa que "nos invita a caminar llevando a Dios en el corazón" ${ }^{2}$, siempre se atuvo a lo que personalmente habia vivido, es decir, a su propia experiencia. Así, en sus obras no ha plasmado más que esa "vivencia personal", esa experiencia que le llevó a existir desde y en Dios, requisito indispensable para que se produzca algún conocimiento divino.

Por otro lado, la experiencia de Dios conduce también a una experiencia de sí, es decir, el conocimiento divino implica -a su vezel conocimiento humano y viceversa, pues "Jamás nos acabamos de conocer si no procuramos conocer a Dios, mirando su grandeza acudamos a nuestra bajeza" ", algo que corrobora igualmente el franciscano Diego de Estella (1524-1578) al afirmar que, "del conocimiento de Dios nace el conocimiento de sí; y del conocimiento de sí, el conocimiento de Dios"61.

Por tanto, ésta siempre le procurará al hombre un cierto ahondamiento de su propia interioridad, ya que -como bien recuerda la misma Santa- "pensar que hemos de entrar en el cielo y no entrar en nosotros, conociéndonos y considerando nuestra miseria y lo que debemos a Dios y pidiéndole muchas veces misericordia, es desatino"62.

Pero, esa "interioridad teresiana" se podría definir como una intimidad que suscita en ella la misma Palabra de Dios y que, a la vez, trasciende en el encuentro personal con El. Así, en ambos, resulta de trascendental importancia el tema del Dios interior, del "Deus interior", pues "Tú, Señor, eres más interior que mis intimidades" ${ }^{63}$, algo que le hará exclamar:

\footnotetext{
58 San Juan Pablo II. Evocación y Plegaria a Santa Teresa de Jesús, 1 Noviembre de 1982.

59 San Juan Pablo II. Ibid.

60 M. I, 2,9.

61 Diego de Estella. De la vanidad del mundo. Impreso en Alcalá de Henares en casa de Iván Gracián, 1597, Tercera Parte, c. XXII (Del conocimiento de Dios).

62 M. II, 1,11.

63 En. Ps. 118/s. 226.
} 
"Paréceme provechosa esta visión para personas de recogimiento, para enseñarse a considerar al Señor en lo muy interior de su alma, que es consideración que más se apega, y muy más fructuosa que fuera de sí-como otras veces he dicho- y en algunos libros de oración está escrito, adónde se ha de buscar a Dios. En especial, lo dice el glorioso San Agustin que ni en las plazas ni en los contentos ni por ninguna parte que le buscaba le hallaba como dentro de sí. Y esto es muy claro ser mejor. Y no es menester ir al cielo, ni más lejos que a nosotros mismos, porque es cansar el espiritu y distraer el alma y no con tanto fruto". ${ }^{64}$

Gracias a todo ello, la "santa interesantisima"65 logra obtener su propia experiencia de Dios, experiencia que intenta describir basándose en una serie de imágenes que -no obstante- pueden inducir al engaño, puesto que "es muy diferente el cómo se ve, a decirse, porque se puede mal dar a entender"66:

"Estando una vez en las Horas con todas, de presto se recogió mi alma, y parecióme ser como un espejo claro toda, sin haber espaldas ni lados ni alto ni bajo que no estuviese toda clara, y en el centro de ella se me representó Cristo nuestro Señor, como le suelo ver. Pareciame en todas las partes de mi alma le veía claro como en un espejo, y también este espejo -yo no sé decir cómo- se esculpía todo en el mismo Señor por una comunicación que yo no sabré decir, muy amorosa"67.

Por todo ello, se reconoce a sí misma como "amante de estas imágenes", puesto que "Tenia tan poca habilidad para con el entendimiento representar cosas que, si no era lo que veía, no me aprovechaba nada de mi imaginación, como hacen otras personas que pueden hacer representaciones adonde se recogen. Yo sólo podia pensar en Cristo como hombre. Mas es asi que jamás le pude representar en mí-por más que leía su hermosura y veía imágenes-, sino como quien está ciego o a oscuras, que, aunque habla con una persona y ve que está con ella (porque sabe cierto que está allí), mas no le ve. De esta manera, me acaecian a mi cuando pensaba en nuestro Señor; a esta causa era tan amiga de imágenes. ¡Desventurados los que por su culpa pierden este bien! Bien parece que no aman al

64 V. $40,6$.

65 Beato Pablo VI. Homilia, 27 Septiembre de 1970.

66 V. 40, 5.

67 V. $40,5$. 
Señor, porque, si le amaran, holgáranse de ver su retrato, como acá aún da contento ver el de quien se quiere bien"68.

De esta forma, la Santa abulense reconoce que dicha experiencia no puede ser sino "cosa de Dios", pues resulta imposible que sea "fruto del mero esfuerzo humano". Por tanto, como bien advierte, no se podría repetir en nosotros "sino cuando Dios nos quiere hacer esta merced"69.

Pero, a veces dicha "merced" se puede ir "apagando", "aletargando", por lo que -rápidamente- habremos de pasar a la acción. Así, no podemos permitir que este "fuego divino" termine por extinguirse en nuestras almas, sino que se ha de salir para buscar señales o estimulos que nos remitan de nuevo a El: "no nos estemos bobos perdiendo tiempo por esperar lo que una vez se nos dio"70.

Para ello, "la cristiana verdadera y la esposa que deseaba ver pronto al Esposo"71 recurrirá a las Sagradas Escrituras (por cuyas verdades "hacemos lo que debemos"72), concretamente al capitulo tercero del libro del Cantar de los Cantares en donde se nos narra cómo la Amada se lanza a las calles y plazas en busca de su Amado, pues en este libro "grandes cosas debe haber y misterios en estas palabras"73. De igual manera, lo hará con el hermoso pasaje agustiniano de Confesiones $X, 6,9$, en el que "el genio de Europa"74 decide salir al encuentro de Dios, entablando para ello un diálogo con todas las criaturas.

Es por todo ello, que acción y contemplación quedan unidas en Santa Teresa, puesto que "Torno a decir que para esto es menester no poner vuestro fundamento sólo en rezar y contemplar, porque sino

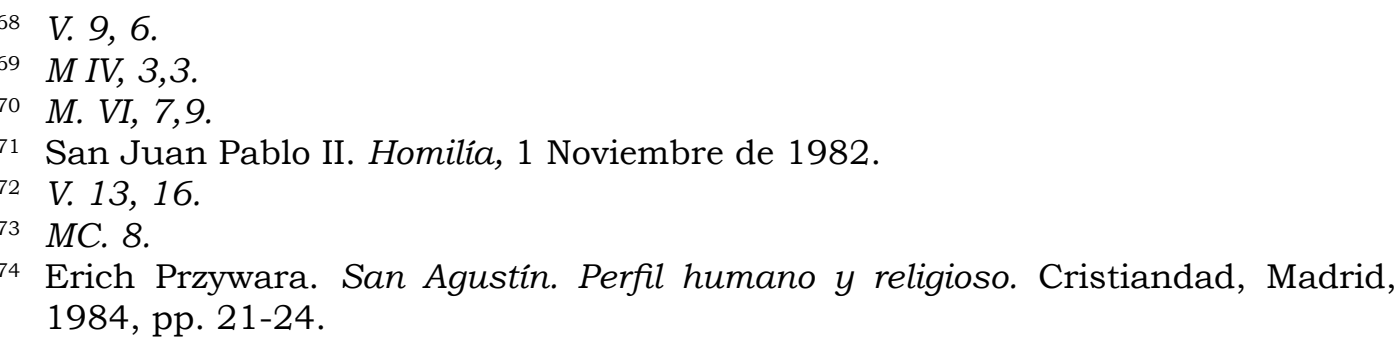


procuráis virtudes y hay ejercicio de ellas siempre, os quedaréis enanas,...creedme que Marta y Maria han de andar juntas para hospedar al Señor, y tenele siempre consigo, y no le hacer mal hospedaje no le dando de comer (Mt. 10, 38-39)"75.

Ya Juan Pablo II subrayó que "Teresa de Jesús fue el instrumento providencial, la depositaria de un nuevo carisma de vida contemplativa que tantos frutos tenia que dar"76, pues es una "santa profundamente contemplativa y eficazmente activa" $"$.

Con todo lo expuesto anteriormente, parece dar un "salto" con respecto a San Agustín, puesto que para él Dios se halla -fundamentalmente- en el interior ("Noli foras ire, in te ipsum redi, in interiore homine hábitat veritas") ${ }^{78}$, aunque ello capacite también para poder encontrarlo en lo exterior.

No obstante, esta "maestra llena de admirable profundidad"79 reconoce que buscarle en la interioridad de uno mismo, resulta ser algo mucho más fructuoso y óptimo (aunque recuerde a sus monjas que también "entre los pucheros anda el Señor"), pues "Esto de apartarse de lo corpóreo, bueno debe ser"

Además, la solución a toda clase de melancolias y males que sufre el hombre se halla cuando -verdaderamente- se reconoce la existencia de un "mundo interior" en el que habita Dios, ya que " $y$ vienen las melancolias y a perder la salud y aun a dejarlo del todo, porque no consideran que hay un mundo interior acá dentro"82.

De esta forma, la vivencia de Dios en lo más íntimo de cada uno se convierte en el camino más seguro y fiable para que el hombre

\footnotetext{
M. VII, 4, 9 y 12.

San Juan Pablo II. Homilia, 1 Noviembre de 1982.

Benedicto XVI. Audiencia General, 2 Febrero de 2011.

Vera rel. 39, 72.

Beato Pablo VI. Homilía, 27 Septiembre de 1970.

"Pues jea, hijas mías!, no haya desconsuelo cuando la obediencia os trajere empleadas en cosas exteriores; entended que si es en la cocina, entre los pucheros anda el Señor ayudándoos en lo interior y exterior" $(F .5,8)$.

81 V. 22, 8.

82 M. IV, 1,9 .
} 
pueda conocerlo con total certeza, a pesar de su inefabilidad, algo en lo que ambos doctores santos convergen: "Nec cum videbis: quia ineffabile est quod vides"83.

Al mismo tiempo, y como ya hemos subrayado, se ha de recurrir a las cosas cotidianas para poder así insinuarle, ya que "nuestros entendimientos, por agudos que fuesen (...) no pueden llegar a considerar a Dios"84.

En definitiva, podemos concluir afirmando que la lectura de las Confesiones (especialmente el capitulo 27 del libro X) reavivó en la madre Teresa el deseo de regresar, de ordenar su interior, pues "Y he aqui que tú estabas dentro de mí y yo fuera, y por fuera te buscaba; y deforme como era, me lanzaba sobre estas cosas hermosas que tú creaste. Tú estabas conmigo, mas yo no lo estaba contigo. Reteniame lejos de ti aquellas cosas que, si no estuviesen en ti, no serian. Llamaste y clamaste, y rompiste mi sordera; brillaste y resplandeciste, y fugaste mi ceguera; exhalaste tu perfume y respiré, y suspiro por ti; gusté de ti, y siento hambre y sed, me tocaste, $y$ abraséme en tu paz"85.

\section{4. "BÚSCAME EN TI, BÚSCATE EN MÍ": EL INEFABLE ENCUENTRO DEL HOMBRE CON DIOS}

"Despegue el corazón de todas las cosas, y busque y hallará a Dios"86. Es así, que Santa Teresa de Jesús posee un óptimo concepto acerca del inmenso valor del hombre, siempre en relación a Dios, pues tanto el amor al prójimo como el amor hacia El han de ir indisolublemente unidos (algo que ya apuntaba San Agustín, puesto que "si amas a la Cabeza, ama también a los miembros"87). Así nos lo describe: "¡Oh, Jesús mio!, cuán grande es el amor que tenéis a los hijos de los hombres, que el mejor servicio se os puede hacer es dejaros a Vos por su amor y ganancia y entonces sois poseido más

\footnotetext{
S. 53, 12.

M. I, 1,1 .

Conf. X, 27,38.

Av. 36.

87 Ep. Jo. 10, 3.
} 
enteramente...Quien no ama al prójimo, no os ama, Señor mio; pues con tanta sangre vemos mostrado el amor tan grande que tenéis a los hijos de Adán"88.

Es por todo lo cual que podemos afirmar como la relación hombreDios ha constituido una constante para todos los tiempos, puesto que afecta a la raíz de la misma condición humana. No obstante, al igual que ocurriese en el "siglo" teresiano ( $;$ Oh desventurados tiempos y miserable vida en la que ahora vivimos...!") (19 $^{89}$ también nuestra época se encuentra sometida a rápidos cambios en los que la conciencia humana, y todo lo que ésta conlleva, está sufriendo una serie de transformaciones que afectan tanto al modo de vivir o expresar, como entender nuestra relación con lo divino. Así, se ha producido el denominado "eclipse de Dios"90.

Sin embargo, esta mística contemplativa insiste en el conocimiento de lo divino con la única finalidad que el hombre pueda llegar al suyo propio, pues éste lo aprenderá sólo en Aquel: "Noverim me, noverim te"

De esta forma, el ser humano puede y debe reconocerse en su Creador, pues "fue hecho a su imagen" ya que "en cada cosita que Dios crió hay más de lo que se entiende, aunque sea una hormiguita"93.

Así, también el amor hacia El irá creciendo en la medida que vayamos conociéndole más, pues "porque también crece el amar mientras más se le descubre lo que merece ser amado este gran Dios y Señor"94.

\footnotetext{
E. 2,2 .

M. VI, 6, 12.

90 Martín Buber. Eclipse de Dios. Estudio sobre las relaciones entre Religión y Filosofia. Ed. Nueva Visión, Buenos Aires, 1970/ Benedicto XVI. Ángelus, 13 Marzo de 2011.

91 Sol. II, $1,1$.

92 Gn. 1, 27.

93 M. IV, 2, 2.

94 M. VI, 11, 1.
} 
Además, tanto para Teresa como para Agustín será dicho amor el único que posea la primacía sobre todo, pues mientras que para aquélla "dirige" ${ }^{\text {95 }}$, para éste poseerá el poder de transformar la esencia de la misma persona, "porque la caridad da muerte en nosotros a lo que fuimos para que cambiemos de ser; hace, pues, en nosotros cierta muerte el amor; de ella habla el que decía: "Habéis muerto, y vuestra vida está escondida con Cristo en Dios" (Col. 3,3)"96.

No obstante, el hombre por sí solo no podría conocerse o reconocerse en Dios si éste no lo concede ${ }^{97}$, pues "todo es dado de Dios" ${ }^{\prime 98}$, idea ésta que podríamos conectar con el "indigens Deo" 99 agustiniano.

Así, si el ser humano busca a Dios es, fundamentalmente, por dos razones:

a) porque tiene noticia de $\mathrm{El} \mathrm{y} \mathrm{b)} \mathrm{porque} \mathrm{busca} \mathrm{la} \mathrm{felicidad.} \mathrm{De}$ esta forma, ambos místicos convergen al señalarlo como la fuente de toda felicidad, ya que mientras el Obispo de Hipona afirma tajantemente que "el hombre feliz es el que posee a Dios"100, la Santa que "representa una de las cimas de la espiritualidad cristiana de todos los tiempos"101 concluye que "quien a Dios tiene nada le falta"102.

Es éste, sin duda, el "eje primordial y fundamental" sobre el que gira la santidad de sus vidas, una santidad para la que fue creada el alma: "No sé qué me diga de este mundo, que en habiendo interés no hay santidad"103. Así, "Recogi entonces unas consideraciones de Teresa de Ávila: "todo es nada, y menos que nada, lo que se acaba y no contenta a Dios” (V. 20,26). ¿Comprendéis por qué un alma deja

95 V. 25.

96 En. Ps. 121, 12.

97 "Mas no puede haber buen pensamiento si Vos no le dais..." (V. 38, 22).

98 V. 10, 2.

99 S. $168,5$.

${ }^{100}$ B. vita 4, 33s.

${ }^{101}$ Benedicto XVI. Audiencia General, 2 Febrero de 2011.

${ }^{102}$ P. 30.

${ }^{103}$ Ep. 160, 4. 
de saborear la paz y la serenidad cuando se aleja de su fin, cuando se olvida de que Dios la ha creado para la santidad? Esforzaos para no perder nunca este punto de mira sobrenatural, tampoco a la hora de la distracción o del descanso, tan necesarios en la vida de cada uno como el trabajo"104.

De esta forma, y como bien apuntó San Juan Pablo II, “Teresa de Jesús es arroyo que lleva a la fuente, es resplandor que conduce a la luz. Y su luz es Cristo, el "Maestro de la Sabiduria" (Camino de Perfección 21,4)"105, al igual que vivió "la santidad de una vida consagrada a la contemplación y, al mismo tiempo, comprometida en la acción"106.

\section{5. "SÓLO DIOS BASTA": MOTIVACIONES AGUSTINIANAS PARA UNA "CONVERSIÓN TERESIANA"}

"Paréceme que ganó grandes fuerzas mi alma de la Divina Majestad, y que debia oir mis clamores y haber lástima de tantas lágrimas. Comenzóme a crecer la afición de estar más tiempo con El..."107.

Con estas palabras, nos relata su "situación personal", situación que -nuevamente- podemos asimilar a la agustiniana, pues "(Tú conoces) los gemidos de mi corazón dirigidos hacia ti y los ríos de mis ojos"108.

De esta forma, ambos muestran un cierto anhelo de conversión hacia Dios, puesto que se reconocen "pecadores e indignos": "Sólo le pedia me diese gracia para que no le ofendiese, y me perdonase mis grandes pecados. Como los veia tan grandes, aun desear regalos ni gustos nunca de advertencia osaba"109, pues "todo me procedia de ser tan pecadora yo y haberlo sido"110.

\footnotetext{
${ }^{104}$ San José María Escrivá de Balaguer. Homilia, 11 Marzo de 1960, en Amigos de Dios. Rialp, Madrid 2009 (c. III: La grandeza de la vida corriente).

105 San Juan Pablo II. Homilia, 1 Noviembre de 1982.

106 Beato Pablo VI. Homilia, 27 Septiembre de 1970.

107 V. 9, 9.

108 Conf. $X, 37,70$.

109 V. 9, 9.

110 V. 28, 16.
} 
Así, halla en el maestro de Hipona un incuestionable "consuelo y amparo". No obstante, el proceso de su conversión no fue tan "desgarrador" como el agustiniano. De esta forma, en dicho proceso se produce como una cierta ruptura de nivel existencial, así como se origina un nuevo nacimiento, es decir, existen dos procesos bien diferenciados: 1) el sujeto religioso más que buscar se siente buscado y 2) el salir de sí, el "descentramiento" de dicho sujeto: "Dicen que el alma se entra dentro de si y otras veces que sale sobre si"111.

De esta forma, para que el alma pueda entrar en contacto con su Creador, deberá despojarse de todo lo exterior, despreciando todas las cosas del mundo, para así poder decir "da lo que mandas y manda lo que quieras" ${ }^{12}$.

Dicha súplica agustiniana suscitó la simpatía de Teresa, la cual llegaría -incluso- a emplearla en su oración personal, pues "así os suplico con San Agustin, con toda determinación, que me deis lo que me mandareis, y mandadme lo que quisiereis; no volveré las espaldas jamás, con vuestro favor y ayuda"113.

Ya cierta autora ${ }^{114}$ llegó a hablar -como en el caso de San Agustín ${ }^{115}$ - hasta de tres (incluso cinco) conversiones en esta "figura luminosa y siempre actual" ${ }^{16}$, aunque podrian resumirse en su empeño de "forzarse para ser monja".

No obstante, para poder conocer su proceso de conversión, hemos de retrotraernos hasta su inicial educación y entorno agustiniano. Así, la autora de Castillo Interior (1577) ingresó -como ya se ha señalado- interna en un monasterio agustino abulense: Nuestra Señora de Gracia. Allí disfrutó tanto de la estima como del afecto de toda la comunidad religiosa, destacando con especial atención

${ }^{111}$ M. IV, 3, 2.

${ }^{112}$ Conf. X, 29,40/X, 31,45/X, 37,60.

113 CA. 4, 9.

${ }^{114}$ Marcelle Auclair. "Les trois conversions de Sainte Thérèse", en Carmel 38 (1955), pp. 5-6.

115 Benedicto XVI. Homilia, 22 Abril de 2007.

${ }^{116}$ San Juan Pablo II. Homilia, 1 Noviembre de 1982. 
a la Madre María de Briceño y Contreras (1498-1584), quien fuera nombrada maestra de novicias con 32 años:

"Dormía una monja con las que estábamos seglares, que por medio suyo parece quiso el Señor comenzar a darme luz, como ahora diré. Pues comenzando a gustar de la buena y santa conversación de esta monja, holgábame en oírla cuán bien hablaba de Dios porque era muy discreta y santa. Esto, a mi parecer, en ningún tiempo dejé de holgarme de oírlo. Comenzó a contarme cosas, cómo ella había venido a ser monja por solo leer lo que dice el evangelio: Muchos son los llamados y pocos los escogidos... Comenzó esta buena compañia a desterrar las costumbres que había hecho la mala (...) Estuve año y medio en este monasterio harto mejorada. Comencé a rezar muchas oraciones vocales (...) A cabo de este tiempo que estuve ya tenía más amistad de ser monja, aunque no en aquella casa por las cosas más virtuosas que después entendi tenian"117.

Un testimonio del agustino Miguel Varona, que fue vicario de dicho convento allá por el siglo XVIII, recogido en su obra inédita Noticias históricas y protocolo del Convento de Gracia (1965), dice que, "Por el conocimiento que habia de las prendas de la Señora Briceño, con aclamación universal fué nombrada por maestra de las niñas seculares, que llaman comúnmente las señoras doncellas de piso, a quienes ella de dia y de noche no se apartaba de su lado; pues de dia para oír misa las llevaba en forma de comunidad al coro y en tribuna aparte cuando el Convento celebraba la misa conventual. Tanta era la observancia y la estrechez en que tenia a la juventud nuestra venerable Doña Maria que, si alguna niña habia de salir a ver a sus padres a la grada, no permitía que estuviese sin que estuviese con ella".

De esta forma, la influencia de dicha religiosa sobre la futura Doctora de la Iglesia Universal llega a tal extremo que -como nos ha dicho anteriormente- deja de sentir "la gran enemistad que tenia con ser monja, que se me habia puesto grandisima"118, pues:

"Gustaba mucho, cuando jugaba con otras niñas, hacer monasterios como que éramos monjas, y yo me parece deseaba serlo"119.

117 V. 2, 10/3,1-2.

118 V. 3, 1.

119 V. 1, 6. 
Por otro lado, retomó también la práctica de la oración, a través de la cual desea conocer "el estado en el que le había de servir", ya que "Comencé a rezar muchas oraciones vocales" pues "por que no penséis se saca poca ganancia de rezar vocalmente con perfección, os digo que es muy posible que, estando rezando el Paternóster, os ponga el Señor en contemplación perfecta, o rezando otra oración vocal. Que por estas vías muestra Su Majestad que oye al que le habla, y le habla su grandeza, suspendiéndole el entendimiento y atajándole el pensamiento y tomándole-como dice-la palabra de la boca, que aunque quiere no puede hablar si no es con mucha pena"120, ya que este tipo de oración "trae consigo mil bienes"121.

Así, con todo ello, la idea de ser religiosa se va consolidando, aunque sólo deseará profesar en aquel convento donde se hallare su "grande amiga"122 hacia la que "tenía mucha afición"123: Juana Juárez, religiosa en el monasterio carmelitano de la Encarnación, en Ávila, puesto que "Miraba más el gusto de mi sensualidad y vanidad que lo bien que me estaba a mí el alma"124, ya que "el mejor y más seguro estado"125 era este el de ser monja.

Sin embargo, su definitiva conversión se producirá (según autores ${ }^{126}$ ) cuando, con 39 años, llegue a sus manos el libro de las Confesiones, algo sobre lo que ya tratamos anteriormente.

Por todo ello, podemos concluir afirmando que es en un ambiente agustiniano donde aquella que "fue fiel a la fe católica"127 retorna y recupera sus hábitos religiosos, pues advierte que el hombre se enajena, se aliena y se olvida de sí mismo cuando se halla separado de Dios. Por tanto, El será la "vida de su vida"128 a quien encuentra

\footnotetext{
${ }^{120}$ C. 25,1 .

${ }^{121}$ C. 47,1 .

${ }^{122}$ V. 3, 2.

${ }^{123}$ V. 3, 1.

${ }^{124}$ V. 3, 2.

${ }^{125}$ V. 3, 5 .

${ }^{126}$ Pierre Blanchard. "La structure augustinienne de la pensé thérésienne", en Rev. Divinitas 7 (1963), pp. 351-386.

${ }^{127}$ Beato Pablo VI. Homilía, 27 Septiembre de 1970.

${ }^{128}$ M. VII, 2,6.
} 
y reconoce dentro de su propia alma, puesto que "no es baja (el alma), hija, pues está hecha a mi imagen"129, ya que:

"Alma, buscarte has en Mi /y a Mi buscarme has en ti./De tal suerte pudo amor,/alma, en mi te retratar,/que ningún sabio pintor/supiera con tal primor/tal imagen estampar./Fuiste por amor criada/hermosa, bella, $y$ asi/en mis entrañas pintada,/si te perdieres, mi amada/Alma buscarte has en Mi./Que yo sé que te hallarás/en mi pecho retratada/y tan al vivo sacada,/que si te ves te holgarás/viéndote tan bien pintada./Y si acaso no supieres/dónde me hallarás a Mî,/no andes de aqui para alli,/ sino, si hallarme quisieres/ a Mi, buscarme has en ti./Porque tú eres mi aposento,/eres mi casa y morada,/y asi llamo en cualquier tiempo,/ si hallo en tu pensamiento/ estar la puerta cerrada./Fuera de ti no hay buscarme,/porque para hallarme a Mi//bastará sólo llamarme,/que a ti iré sin tardarme/y a Mí buscarme has en ti"130.

Por otro lado, la autora de las Fundaciones (1573-1582) ofrece al hombre de hoy un "nuevo elemento" en su continua búsqueda de Dios, pues "Acaecióme a mi una ignorancia al principio, que no sabia que estaba Dios en todas las cosas y como me parecia estar tan presente pareciame imposible. Dejar de creer que estaba alli no podia, por parecerme casi claro habia entendido estar alli su misma presencia. Los que no tenían letras me decian que estaba sólo por gracia. Yo no lo podia creer porque como digo pareciame estar presente y asi andaba con pena. Un gran letrado de la Orden de Santo Domingo me quitó de esta duda, que me dijo estar presente y cómo se comunicaba con nosotros, que me consoló harto"131.

Pero, será "Un dia de San Pablo, estando en misa, se me representó toda esta humanidad sacratísima..."132. Nuevamente, ambos Doctores (Agustín y Teresa) convergen en el "verdadero caballero de Jesucristo y príncipe de su Iglesia"133, pues "Miremos al glorioso San Pablo, que no parece se le caía de la boca siempre Jesús, como quien le tenía bien en el corazón. Yo he mirado con cuidado, después que esto he entendido, de algunos santos, grandes contemplativos, y no

\footnotetext{
129 CC. 41

${ }^{130}$ P. 4.

${ }^{131}$ V. $18,15$.

132 V. 28, 3.

${ }^{133}$ F. $10,11$.
} 
iban por otro camino..." 134 , ya que "A mi me dio tanto temor y pena que no sabía qué me hacer. Todo era llorar. Y estando en un oratorio muy afligida no sabiendo qué había de ser de mí, lei en un libro-que parece el Señor me lo puso en las manos- que decía San Pablo "que era Dios muy fiel, que nunca a los que le amaban consentía ser del demonio engañados" (1Cor. 10,13). Esto me consoló muy mucho"135.

Es por ello que "la doctrina de Teresa de Jesús está en perfecta sintonía con una teología de la oración que presenta San Pablo, el apóstol con el que ella se identificaba tan profundamente"136.

De esta forma, podemos calificarlo de solamen sanctorum, consuelo de dos "grandes santos y enamorados de Dios", claves para una adecuada y correcta comprensión de la historia de la Iglesia, pues ellos serán -ante todo- "dos místicos deudores de lo divino".

\section{AGUSTÍN Y TERESA: DOS MíSTICOS “DEUDORES DE DIOS”}

Los místicos son aquellas personas que, aunque nos hablan, no usan palabras propias para comunicarse, es decir, no hablan desde sí mismos. Aunque su voz está en y dentro de ellos, sin embargo parece que la pronuncie y articule un "ser" completamente distinto a ellos mismos, un "ser superior", al que identificamos con Dios. Asimismo, ellos se transformarán en "meros transmisores", por lo que podríamos definirlos como "deudores de Dios". Es por ello que, autores como Bergson (1859-1941), se preguntarán cómo han podido llegar a ser comparados con enfermos ${ }^{137}$

Es cierto que en todos ellos la sensibilidad estética es un "don común", algo que los llevará a percibir ciertos "encantos" que sólo sus almas privilegiadas serán capaces de avistar. Es por ello que la

\footnotetext{
${ }^{134}$ V. $22,7$.

${ }^{135}$ V. 23, 15.

${ }^{136}$ San Juan Pablo II. Homilia, 1 Noviembre de 1982.

${ }^{137}$ Henri Bergson. Las dos fuentes de la moral y la religión. Editorial Sudamericana, Buenos Aires, 1962, pp. 228-229.
} 
"madre y maestra de las personas espirituales"138 quedó gratamente sorprendida ante la sensibilidad poética del Obispo de Hipona. De esta forma, será la "belleza del canto"139, con su poder para elevar a las almas", un claro ejemplo que una y "cale" más hondamente en la capacidad sensible de ambos místicos:

"Cuando recuerdo las lágrimas que derramé con los cánticos de la Iglesia en los comienzos de mi conversión, y lo que ahora me conmuevo, no con el canto, sino con las cosas que se cantan, cuando se cantan con voz clara y una modelación convenientísima, reconozco de nuevo la gran utilidad de esta costumbre"140; "iba ya a salirse el alma (si no hubiese cesado el canto que oyó cantar a una buena voz), del gran deleite $y$ suavidad que nuestro Señor le daba a gustar"141.

Para ambos, Dios es tan real como la vida misma, pues -a diferencia del "dios filosófico"- no es un mero concepto o una mera palabra pronunciada, sino una Palabra que nos pronuncia y una Realidad que nos instituye ${ }^{142}$. A la vez, posee tiempo e historia para el hombre, así como toma palabra y carne, al mismo tiempo que se expresa existiendo y consistiendo con/para nosotros. Es por todo ello que, mientras los demás seres humanos sólo concluyen que existe y hay un Dios, ellos verdaderamente lo saben.

Dios se manifiesta al hombre como amor, de lo cual es muy consciente la mística, ya que "Dios es amor y es objeto de amor: he aqui toda la contribución del misticismo"143. Por tanto, resultaría del todo imposible el poder pensar el ser si -al mismo tiempo- no admitiésemos que existe en $\mathrm{El}$ un principio amoroso con el que crea y comunica todo lo bello, bueno y verdadero. De ahí, se colige que tanto mística como metafísica "caminen juntas", estén llamadas a la mutua convivencia.

No obstante, podemos considerar que aquélla es anterior a ésta, de modo similar a como el Creador es antes de lo creado, lo existente

\footnotetext{
138 Beato Pablo VI. Homilia, 27 Septiembre de 1970.

139 "el deleite de los oídos" (conf. X, 33,50).

140 Conf. $X, 33,50$.

141 CA. 7, 2.

142 Olegario González de Cardedal. "Teresa de Jesús”, 11 Octubre de 2001.

${ }^{143}$ Ibid.
} 
antes de lo existencial. Así, dicha corriente mística resulta ser autónoma, es decir, ni necesita ni requiere la autorización de otra disciplina para poder existir o-incluso- sobrevivir, pues no es más que la experiencia primigenia de todo ser humano que se muestre abierto al Absoluto, al ser, al hombre y al sentido de su historia.

De esta forma, el misticismo supone una nueva forma de comprender y entender, suponiendo así un "desafio o reto" para la metafisica occidental. Por todo ello, Santa Teresa ofrece un nuevo perfil de místico:

Todo lo creado nos ayuda a alabar a Dios, pues aquí se hallan sus huellas. Así, mientras que -en un primer momento- advierte que "cuando veo alguna cosa hermosa, rica, como agua, campos, olores, música...paréceme no lo quería ver ni oír..."144, posteriormente añadirá que "Aprovéchame a mi ver también campos, agua, flores, en esa cosa hallara yo memoria del Criador"145. De igual forma, advierte a sus monjas que: "Esta casa es un cielo si se le puede haver en la tierra para quien se contenta sólo de contentar a Dios y no hace caso de contento suyo; tiénese muy buena vida"146.

En este sentido, de nuevo, la Santa converge con San Agustín, pues, "Rodea con tu ánimo todo el universo de las criaturas; ellas te clamarán de todas parte: "Dios me ha hecho". Todo lo que te deleitare en el arte va en encomio del artífice; mucho más, si recorres todas las cosas, su consideración te elevará a la alabanza del artífice"147.

También hemos de destacar la "inagotable capacidad reformadora" de Teresa de Jesús, una reforma que irá desde la misma Iglesia hasta la sociedad. Por tanto, oración y acción será un "útil binomio" para llevar a cabo todo esto, pero siempre -sin olvidar-al servicio de la Iglesia.

\footnotetext{
${ }_{144}$ CC. $1,18$.

${ }^{145}$ V. $9,5$.

146 C. 13, 7.

${ }_{147}$ En. Ps. 26, 2, 12.
} 


\section{VOCES MONACALES QUE RESUENAN EN LA IGLESIA}

Un punto en común que une a ambos místicos será su profundo amor a la Iglesia. Así, mientras que para San Agustín resultará ser del todo imposible recibir el don del Espíritu Santo si no se ama previamente a la Iglesia ${ }^{148}$, la Santa de valores indiscutibles morirá repitiendo humildemente que "Al final, muero como hija de la Iglesia", a la que "en todo me sujeto a lo que tiene (la Santa Iglesia católica romana), que en ésta vivo y protesto y prometo vivir y morir"149.

Por otro lado, Pablo VI afirma que "En su personalidad se aprecian los rasgos de su patria: la reciedumbre de espíritu, la profundidad de sentimientos, la sinceridad de alma, el amor a la Iglesia"150.

No obstante, su voz se ha extendido "más allá de dicha Iglesia Católica, suscitando simpatias a nivel ecuménico, y trazando puentes de diálogo en los tesoros de espiritualidad de otras culturas religiosas"151.

Su fidelidad y servicio a la Iglesia, no consistió más que en proponer un programa de vida basado tanto en las virtudes evangélicas como humanas, junto a la oración. Así, Benedicto XVI enumera las siguientes ${ }^{152}$ :

Evangélicas: desapego de los bienes o pobreza evangélica; amor mutuo como elemento esencial de la vida comunitaria y social; humildad como amor a la Verdad; determinación como fruto de la audacia cristiana y esperanza teologal, que describe como sed de agua viva.

148 "Recibimos nosotros el Espíritu Santo si amamos la Iglesia, si vivimos unidos en caridad y nos gloriamos del nombre de católicos y de la fe. Creamos, hermanos; en la proporción con la que ama cada uno a la Iglesia, recibe el Espiritu Santo" (Jo. ev.tr. 32,8).

${ }^{149}$ M. VII, epílogo, 24.

150 Beato Pablo VI. Homilia, 27 Septiembre de 1970.

${ }^{151}$ San Juan Pablo II. Homilia, 1 Noviembre de 1982.

${ }^{152}$ Benedicto XVI. Homilia, 2 Febrero de 2011. 
Humanas: afabilidad; veracidad; modestia; amabilidad; alegría y cultura.

Por otro lado, se encuentra la oración, a la cual define como "tratar de amistad, estando muchas veces tratando a solas con quien sabemos nos ama"153, es decir, es vida que lleva al alma hacia Dios y por la cual el cristiano podrá "arrimarse, allegarse y hacerse un espíritu con El"154.

Gracias a ésta, la vida del cristiano va creciendo, a la vez que se puede ir descubriendo la acción misericordiosa y providente de Dios para cada persona. Así, para el maestro de Hipona será capaz de "embellecer" nuestro andar peregrino hacia la Jerusalén Celeste:

"Nuestro camino, por donde vamos a la perfección, lo limpia la oración pura" 155 .

De esta manera, Santa Teresa -en su deseo de difundirla- "con frecuencia interrumpe el relato o la exposición para prorrumpir en una oración"156, una oración que debe estar basada en la humildad, pues "Lo que yo he entendido es que todo este cimiento de la oración va fundada en la humildad y que, mientras más se abaja un alma en la oración, más la sube Dios (Lc. 14,11)"157.

En definitiva, ambos poseerán un profundo sentido eclesial que les llevará -en todo momento- a defender, guardar y preservar su unidad: "El coro es la concordia de los cantos. Si cantamos en el coro, hagámoslo al unísono. En el coro de los cantores, una voz disonante ofende el oido y estropea el coro. Pero una voz desentonada rompe la armonía, ¿cómo la herejía no descentrará el concierto de los que alaban a Dios?"158.

\footnotetext{
153 V. 8, 5.

${ }_{154}$ M. VII, 2,5.

155 Perf. Just. 9, 20.

156 Benedicto XVI. Homilia, 2 Febrero de 1982.

157 V. 22, 11.

158 En. Ps. 149, 7.
} 


\section{A MODO DE CONCLUSIÓN: "YO SOY MUY AFICIONADA A SAN AGUSTÍN"}

A lo largo del presente trabajo, se ha intentado mostrar cómo el espíritu agustiniano -fundamentalmente la lectura de Confesiones- influye de manera decisiva en Teresa de Jesús, ya desde sus comienzos como educanda en Nuestra Señora de Gracia: interioridad, pecado original, idea del mal o muerte, etc.

No obstante, con todo ello no pretendemos negar que la gran mística española posea su propia personalidad, pues ella es "desde sí misma y no desde ningún otro". Tampoco intentamos sugerir que fuese discipula de San Agustín o que marcase decisivamente su amplio y vasto pensamiento.

La Santa que "se hiciera palabra viva acerca de Dios, invitándonos a la amistad con Cristo"160 no nos ha dejado ningún comentario sobre alguna obra agustiniana, así como las citas serán rápidas y escasas.

No obstante, sí se puede aducir una cierta simpatía y afinidad hacia el "heredero de Mónica"161, pues ambos perseguirán la misma meta: buscar a Dios para darse del todo a El. Así, ambos "buscaron juntos creyendo lo que ahora estarán disfrutando viendo", pues "también me parece me aprovechó mucho para conocer nuestra verdadera tierra y ver que somos acá peregrinos" ${ }^{162}$.

\footnotetext{
159 V. 9, 7.

${ }^{160}$ San Juan Pablo II. Homilia, 1 Noviembre de 1982.

${ }^{161}$ Francisco. Homilia, 28 Agosto de 2013.

162 V. 38, 6.
} 